\title{
PENINGKATAN DAYA SAING UKM SEHATI MELALUI OPTIMALISASI PENGGUNAAN TEKNOLOGI DAN PENGELOLAAN MANAJERIAL
}

\author{
YOGI GINANJAR ${ }^{1}$, NITA HERNITA ${ }^{2}$, WULAN RIYADI ${ }^{3}$ \\ Program Studi Akuntansi ${ }^{1,3}$, Program Studi Manajemen ${ }^{2}$ \\ Universitas Majalengka \\ J1. Raya K H Abdul Halim No.103, Kabupaten Majalengka, Jawa Barat 45418 \\ *e-mail:yogi.ginanjar@unma.ac.id
}

\begin{abstract}
UKM Sehati which is used as a partner in this PKM has problems that are of special concern to find solutions. Partners do not have permanent employees who can maintain product quality, so processed products are often different from the previous taste and texture. Employees do not have extensive knowledge of recording and bookkeeping, so that the resulting financial statements are not in accordance with accounting standards. The production equipment used is still simple, both for processing aleksis (krispi catfish) and shredded catfish. The sealer machine for gluing the packaging is too small, causing the product resistance to be not optimal. The marketing that has been done has not touched the online market. The product does not yet have a halal label and nutritional value information so that the product cannot enter minimarkets and even supermarkets. Mitra's knowledge of catfish farming as a raw material has not been maximized, which causes the catfish mortality rate to reach $15 \%$. Based on the findings regarding the problem, the priority is to find solutions to problems in improving various aspects. Among them are managerial aspects related to finance and human resources in an effort to increase community capacity. Furthermore, the technological aspects in an effort to improve product quality. Changes in marketing aspects towards digitalization and broader marketing aspects by obtaining halal labels and information on nutritional values. The specific goals and targets in this community service are to assist Sehati SMEs in improving product quality and competitiveness through the use of technology and managerial management. The method used in an effort to implement the solution above is by holding partner bookkeeping training every 2 weeks, training on the use of deep frying machines, ADR MPD 140 machines and sealer machines (so that product durability is longer and the production process is more effective and efficient), making management information system, create social media (facebook and instagram), join various e-commerce (shopee, Bukalapak, tokopedia and others), create product information website, participate in culinary exhibitions and bazaars, facilitate the inclusion of halal logos and value information nutrition in packaging, and holding training on catfish farming so that the results are maximized. The output produced is in the form of publications in the form of journals and intellectual property rights.
\end{abstract}

Keywords: Sehati UKM, Use of technology, Managerial Management, Cibentar Majalengka Village

\section{ABSTRAK}

UKM Sehati yang dijadikan Mitra dalam PKM ini memiliki permasalahan yang menjadi perhatian khusus untuk dicarikan solusinya. Mitra tidak memiliki karyawan tetap yang bisa 
menjaga kualitas produk, sehingga produk olahan seringkali berbeda dari cita rasa dan tekstur sebelumnya. Karyawan belum memiliki pengetahuan luas mengenai pencatatan dan pembukuan, sehingga laporan keuangan yang dihasilkan belum sesuai standar akuntansi. Alat produksi yang digunakan masih sederhana baik untuk olahan aleksis (anak lele krispi) maupun abon lele. Mesin sealer untuk merekatkan kemasan terlalu kecil sehingga menyebabkan ketahanan produk tidak maksimal. Pemasaran yang dilakukan belum menyentuh pasar online. Produk belum memiliki label halal dan informasi nilai gizi sehingga produk belum bisa masuk ke minimarket bahkan supermarket. Pengetahuan Mitra terhadap budidaya ikan lele sebagai bahan baku pun belum maksimal, yang menyebabkan tingkat kematian ikan lele mencapai $15 \%$. Berdasarkan temuan mengenai permasalahan, maka prioritas untuk mencarikan solusi permasalahan dalam memperbaiki berbagai aspek. Diantaranya aspek manajerial terkait bidang keuangan dan Sumber Daya Manusia dalam upaya peningkatan kapasitas masyarakat. Selanjutnya aspek teknologi dalam upaya perbaikan kualitas produk. Perubahan aspek pemasaran ke arah digitalisasi serta aspek pemasaran yang lebih luas dengan mendapatkan label halal dan informasi nilai gizi. Tujuan dan Target khusus dalam pengabdian masyarakat ini adalah untuk membantu UKM Sehati dalam peningkatan kualitas produk dan berdaya saing melalui penggunaan teknologi dan pengelolaan manajerial. Metode yang digunakan dalam upaya menerapkan solusi di atas yaitu dengan diadakannya pelatihan pembukuan mitra setiap 2 minggu sekali, pelatihan tentang penggunaan mesin deep frying, mesin ADR MPD 140 dan mesin sealer (agar ketahanan produk lebih lama dan proses produksi lebih efektif serta efisien), membuat sistem informasi manajemen, membuat media sosial (facebook dan instagram), bergabung dengan berbagai e-commerce (shopee, bukalapak, tokopedia dan lain-lain), membuat website informasi produk, mengikuti pameran dan bazar kuliner, memfasilitasi untuk mencantumkan logo halal dan informasi nilai gizi dalam kemasan, dan mengadakan pelatihan tentang budidaya ikan lele agar hasilnya lebih maksimal. Luaran yang dihasilkan berupa publikasi berupa jurnal dan HAKI.

Kata kunci: UKM Sehati, Penggunaan teknologi, Pengelolaan Manajerial, Desa Cibentar Majalengka

\section{PENDAHULUAN}

Dunia dikagetkan dengan adanya pandemi Covid-19. Virus ini melanda seluruh negara, salah satunya Indonesia. Pandemi ini memberikan dampak serius di bidang ekonomi. Tidak hanya industri besar tetapi juga pelaku UKM yang terdampak secara langsung terhadap penurunan omzet.

Hal ini menuntut para pelaku UKM di Majalengka memiliki daya saing kuat untuk menunjang perekonomian kerakyatan (Bismala, dkk, 2018). Menghadapi Era New Normal, Dinas Perdagangan dan Perindustrian Kabupaten Majalengka mendorong para pelaku UKM untuk melakukan migrasi ke arah digitalalisasi (Henry, 2019). Hal itu selain mengembangkan teknologi- informasi yang kian

pesat, sekaligus untuk memutus mata rantai penyebaran Covid-19 (Yulianto, 2020). UKM Sehati yang berada di Desa Cibentar Kecamatan Jatiwangi Kabupaten Majalengka adalah industri yang bergerak di bidang pangan dan perikanan. UKM Sehati ini fokusnya tidak hanya budidaya ikan lele tetapi juga produk olahan ikan. Khususnya adalah makanan sehat berupa olahan ikan lele yang dibuat menjadi abon lele dan anak lele krispi (Aleksis). UKM ini didirikan pada tanggal 18 januari 2017 dengan jumlah pengelola sebanyak 3 orang dan penggagas utamanya 
adalah bapak Nur Aldi. Berikut adalah gambar UKM Sehati beserta produk:
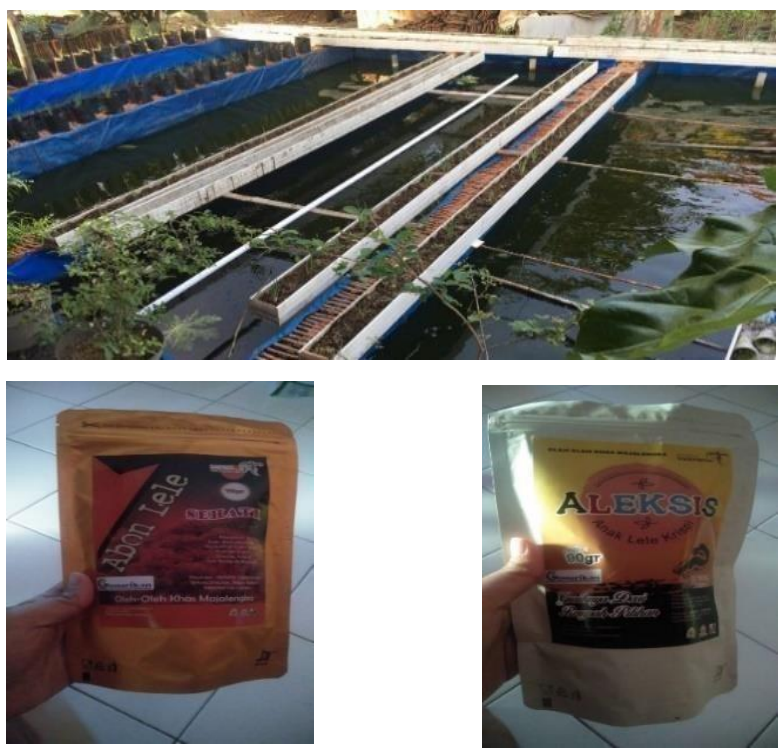

Gambar 1. Kolam Terpal Ikan Lele dan Produk UKM

Produk aleksis ini menjadi produk unggulan UKM Sehati, karena selain rasanya yang enak yaitu rasa original dan pedas, aleksis ini juga merupakan produk yang unik dari beberapa produk lainnya. Selain olahan anak ikan lele krispi ini, ada produk lain yang diolah dan dipasarkan oleh UKM Sehati diantaranya abon lele, kerupuk kulit ikan lele dan abon ikan patin. Penjualan aleksis ini rata-rata setiap bulannya terjual mencapai 2000 bungkus. Era new normal ini membuat omzet penjualan UKM Sehati mengalami fluktuasi, dapat dilihat pada trend penjualan bulan Januari-Juli 2020 pada tabel dibawah ini:

Tabel 1. Penjualan Produk Aleksis pada Bulan Januari

\begin{tabular}{|c|l|c|c|}
\hline $\begin{array}{c}\text { N } \\
\mathbf{0}\end{array}$ & \multicolumn{1}{|c|}{ Bulan } & $\begin{array}{c}\text { Jumlah } \\
\text { Penjual } \\
\text { an }\end{array}$ & $\begin{array}{c}\text { Selisih } \\
\text { Penjualan dari } \\
\text { Bulan } \\
\text { Sebelumnya }\end{array}$ \\
\hline 1 & Januari & 2000 bungkus & - \\
\hline 2 & Februari & 2000 bungkus & - \\
\hline 3 & Maret & 1850 bungkus & $(150)$ \\
\hline 4 & April & 1000 bungkus & $(850)$ \\
\hline 5 & Mei & 800 bungkus & $(200)$ \\
\hline
\end{tabular}

\begin{tabular}{|c|l|c|c|}
\hline 6 & Juni & 500 bungkus & $(300)$ \\
\hline 7 & Juli & 650 bungkus & 150 \\
\hline
\end{tabular}

Sumber : Data UKM Sehati, diolah Penulis (2020)

Tabel diatas dapat dilihat UKM Sehati mengalami fluktuasi, terlebih melihat trend nya mengalami penurunan dari bulan ke bulan semenjak pandemi ini. Penurunan drastis penjualan pada bulan april sebelumnya berjumlah 1850 bungkus menjadi 1000 bungkus dengan tingkat selisih yang cukup tinggi yaitu 850 bungkus. Hal ini memicu pelaku UKM untuk berpikir keras dalam upaya penanggulangan kemerosotan penjualan demi terjaganya keseimbangan perekonomian yang ada. Dampak dari penerapan PSBB, semua toko tujuan pemasaran UKM Sehati banyak yang tutup sementara, sehingga sangat berpengaruh terhadap produksi yang dihasilkan. Ditambah lagi Mitra belum melakukan pemasaran secara online sehingga produksi sangat minim. Berdasarkan hasil analisis situasi oleh Tim PKM yang diperkuat dengan wawancara Mitra, maka dapat disimpulkan bahwa masih banyak permasalahan yang saling terkait dan cukup serius untuk segera dicarikan solusinya, agar ada keberlanjutan produk UKM Sehati apalagi di tengah kondisi pandemi ini. Tim pengabdian masyarakat mengidentifikasi masalah utama yang dialami Pelaku UKM Sehati di Desa Cibentar memiliki tantangan cukup besar pada kondisi pandemi Covid-19. Seiring dengan berkembangnya dunia. industri saat ini, berbagai macam permasalahan dihadapi oleh UKM Sehati, diantaranya:

A. Aspek Manajerial (SDM)

1) Mitra tidak memiliki karyawan tetap, terkadang sering berganti-ganti sehingga berdampak pada cita rasa dan tekstur produk yang dihasilkan;

2) Keterbatasan SDM baik dalam proses produksi maupun pencatatan keuangan, karena sejauh ini hanya memanfaatkan tetangga yang sedang menganggur saja.

\section{B. Aspek Keuangan}

1) Karyawan belum memiliki pengetahuan mengenai pencatatan dan pembukuan; 
2) Mitra belum memiliki laporan keuangan sesuai standar sehingga tidak dapat dijadikan bahan evaluasi dan pengambilan keputusan.

C. Aspek Teknologi

1) Alat produksi yang digunakan masih sederhana baik untuk olahan aleksis maupun abon lele sehingga waktu yang dibutuhkan untuk produksi cukup lama dan kualitas produk belum bisa maksimal khususnya dalam hal ketahanan produk dan tekstur produk;

2) Penggunaan mesin sealer perekat kemasan yang digunakan terlalu kecil sehingga udara dalam kemasan sehingga kualitas produk belum maksimal.

\section{Aspek Pemasaran}

1) Kurangnya promosi karena barang hanya sebatas dipajang di etalase toko tertentu;

2) Mitra belum menyentuh pemasaran online karena pengetahuan masihterbatas;

3) Belum memiliki label halal dan informasi nilai gizi sehingga produk tidak bisa masuk ke minimarket dan supermarket.

4) Pengelolaan Bahan Baku

Mitra belum memiliki pengetahuan yang lebih luas terkait pembudidayaan ikan lele sehingga tingkat kematian mencapai $15 \%$. Berdasarkan temuan di lapangan mengenai permasalahan yang terjadi pada UKM Sehati Desa Cibentar Kecamatan Jatiwangi Kabupaten Majalengka, maka prioritas tim PKM dan Mitra sepakat untuk mencarikan solusi permasalahan guna memecahkan masalah yang dihadapi pelaku UKM Sehati.

\section{METODE PELAKSANAN}

Metode pelaksanaan kegiatan pengabdian masyarakat ini diawali dengan mengidentifikasi masalah mitra, mengidentifikasi solusi, memilih solusi yang paling memungkinkan dan tepat bagi mitra, melaksanakan pengabdian yang terdiri dari membuat rencana bisnis jangka panjang dengan bisnis model canvas, merapikan pencatatan keuangan, dan menyediakan alat produksi yang dibutuhkan mitra. terakhir, kami melakukan pendampingan terhadap usaha mitra. Secara umum metode yang dilakukan adalah sebagai berikut:

1. Metode yang digunakan dari aspek manajerial yaitu pelatihan dan pendampingan kepada Mitra. Sumber daya manusia yang dipekerjakan oleh Mitra juga akan dibimbing untuk paham sistem informasi akuntansi dan sistem informasi manajemen.

2. Metode lainnya yang digunakan dalam aspek teknologi yaitu menyarankan mitra beralih menggunakan alat canggih berupa mesin deep frying, mesin ADR MPD 140 dan mesin sealer agar produk dapat bertahan lama masa kadaluwarsanya sehingga dapat menurunkan risiko kerugian. Tim PKM akan melakukan pembinaan pemasaran online secara berkala, bergabung bersama e-commerce dan situs penjualan online lainnya.

3. Uraian kerja untuk mendukung metode yang ditawarkan yaitu mempersiapkan sumber daya manusia untuk dibekali pelatihan serta pendampingan untuk pencatatan dan pembuatan laporan keuangan yang berkualitas. Selain aspek manajerial, dari sisi aspek teknologi juga diperlukan pembekalan pelatihan tata cara penggunaaan mesin.

4. Perbaikan dalam budi daya ikan lele dengan cara adanya pelatihan terhadap UKM Mitra Sehati guna menurunkan tingkat kematian ikan lele yang masih tinggi Selain itu, perlu adanya pelatihan secara rutin untuk pemasaran online dan mengelola toko online.

5. Mitra maupun pendamping, agar maksud dan tujuan yang diinginkan UKM Sehati 
dapat tercapai. Dengan perbaikan aspek manajerial, perbaikan aspek teknologi, perbaikan dari aspek pemasaran, ditambah dengan promosi dan pemasaran online mengikuti perkembangan revolusi industri 4.0.

6. Pendampingan akan tetap dilakukan secara berkala untuk melihat perkembangan dari aspek manajerial, aspek teknologi dan aspek pemasaran.

\section{HASIL DAN PEMBAHASAN}

Sesuai dengan metode pengabdian yang kami lakukan. Pertama kami melakukan identifikasi atas permasalahan mitra. Langkah kedua mengidentifikasi solusi yang relevan dengan permasalahan mitra. Kemudian ketiga kami memilih solusi dari masalah yang paling mungkin dilakukan. Selanjutnya kami melaksanakan pengabdian berdasarkan solusi permasalahan yang mungkin dilakukan tersebut.

Adapun rangkaian pelaksanaan pendampingan yang kami lakukan yaitu, pelatihan pembukuan mitra, pemberian alat penunjang untuk produksi, membuat sistem informasi, promosi dan pemasaran lewat digital serta pelatihan budidaya lele.

\section{ASPEK MANAJERIAL (SDM)}

Peningkatan mitra dari aspek manajerial bisa dengan pelatihan penguatan untuk pengelola dan pelaku usaha seperti pada gambar berikut

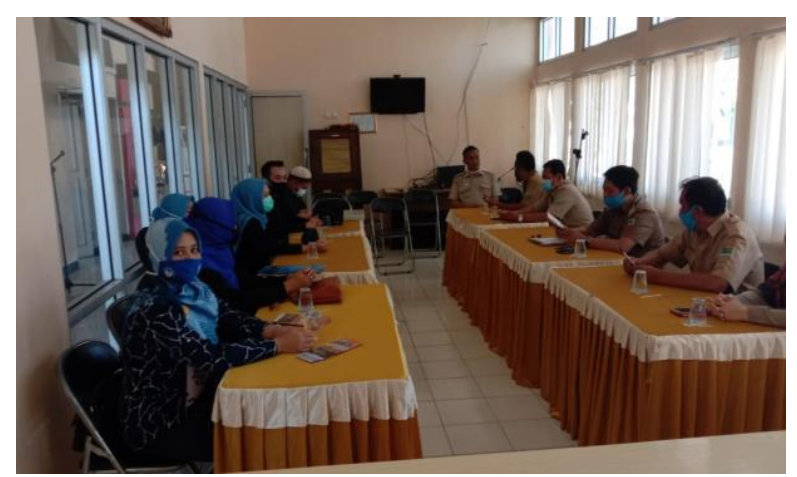

Gambar 2. Pelatihan Peningkatan Kapasitas SDM

\section{ASPEK KEUANGAN}

Peningkatan mitra dari bidang keuangan, kami melakukan pendampingan pembuatan laporan keuangan dalam bentuk pelatihan pembukuan mitra, adapun kegiatan tersebut dapat terlihat pada gambar dibawah ini:

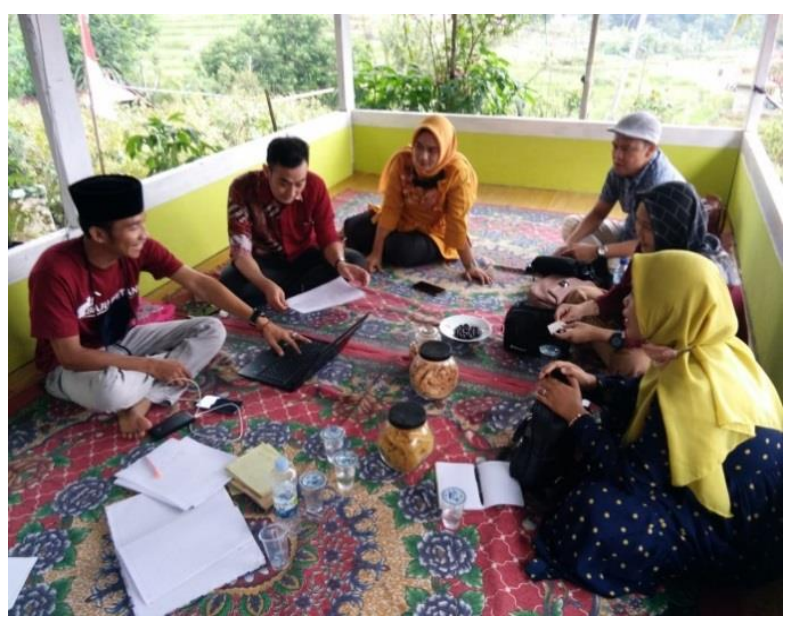

Gambar 3. Pelatihan Pembukuan Mitra

Pelatihan pembukuan mitra dilakukan setiap 2 minggu sekali agar mitra dapat membuat catatan keuangan harian, laporan laba rugi, laporan arus kas, laporan posisi keuangan, laporan perubahan ekuitas dengan menggunakan sistem akuntansi yang mudah dipahami.

\section{ASPEK TEKNOLOGI}

Adapun aspek teknologi yang diberikan tim pengabdian masyarakat yaitu dalam bentuk pembuatan sistem informasi seperti gambar di bawah ini:

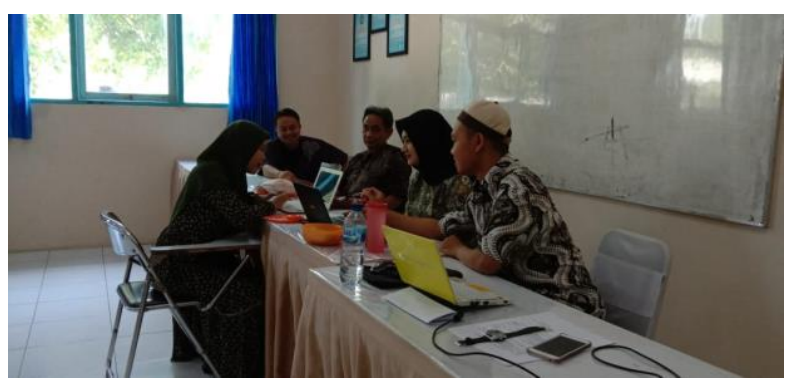

Gambar 4. Pembuatan Sistem Informasi 
Membuat sistem informasi manajemen dengan time schedule yang tepat dan mudah dipahami sehingga jadwal produksi tidak pernah terganggu karena kekosongan tenaga kerja yang sudah memahami proses produksi. Membuat list tenaga kerja tambahan jika suatu saat diperlukan dan diberikan pelatihan sejak awal.

\section{ASPEK PEMASARAN}

Aspek pemasaran untuk peningkatan kapasitas mitra dengan cara memberikan pelatihan serta workshop digitalisasi promosi dan pemasaran produk sebagai berikut:

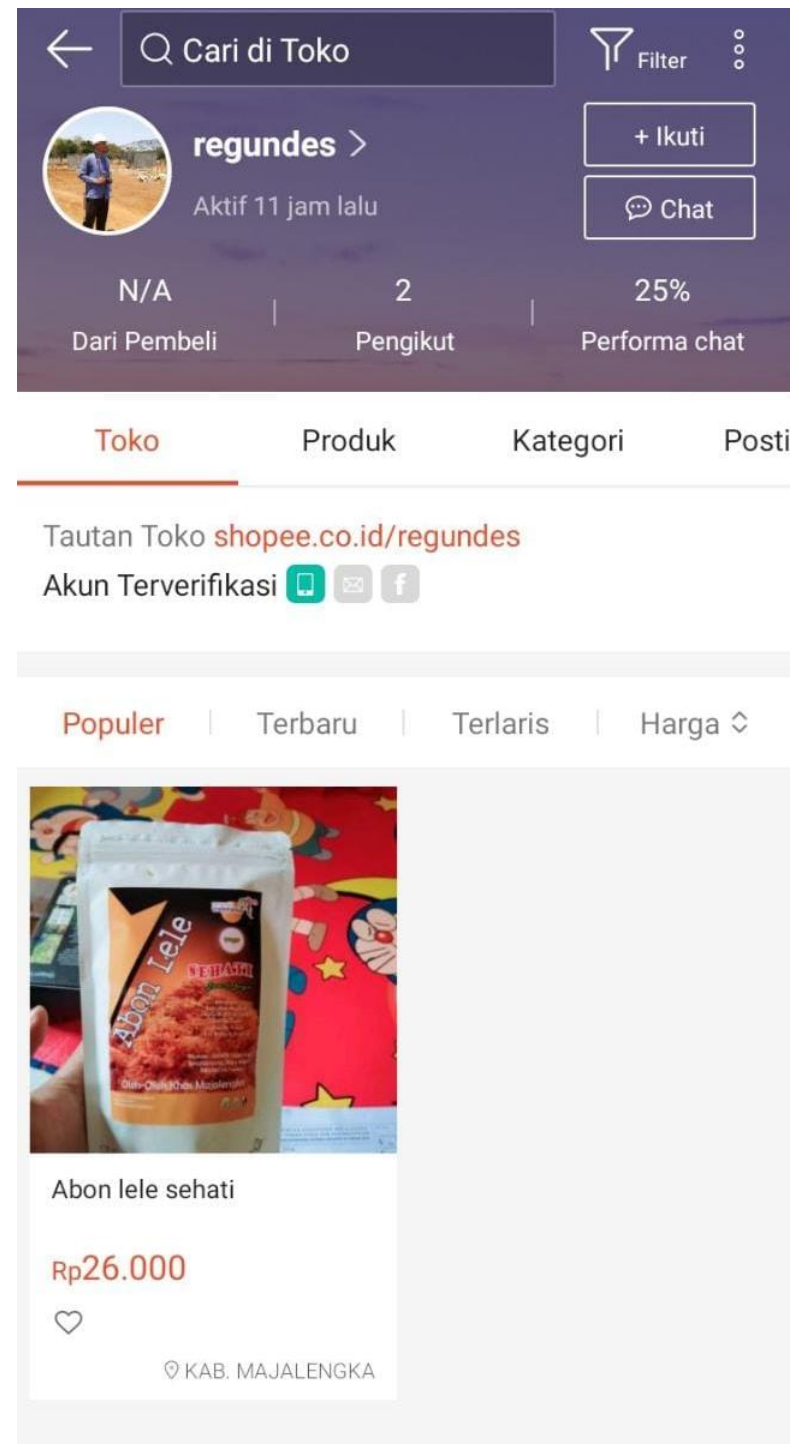

Gambar 5. Digitalisasi promosi dan pemasaran produk
Membuat media facebook dan instagram. Bergabung dengan berbagai e-commerce yaitu shopee dan tokopedia. Membuat website informasi produk dan mengikuti bazar/ pameran.

\section{KESIMPULAN}

Tujuan pengabdian ini adalah untuk memberikan solusi atas permasalahan mitra berupa:

1. Kemampuan pengelola dan pelaku usaha dalam memanajemen seluruh aspek serta meningkatnya kapasitas SDM

2. Kemampuan dalam pembukuan

3. Penambahan sarana (alat dan sistem informasi manajemen,

4. Promosi dan pemasaran lewat digital serta pelatihan budidaya lele.

Hasil yang kami peroleh setelah melakukan pengabdian adalah mitra memperoleh alat produksi secara hibah. Tingkat produksi mitra mengalami peningkatan dalam sehari. Mitra memiliki konsep pemasaran melalui bisnis online, mitra memiliki rencana dan target pasar yang lebih jelas. Selain itu, mitra juga dapat mengidentifikasi kemungkinan pendapatan dan beban yang belum terindentifikasi. Terakhir, mitra telah memiliki laporan keuangan dengan sistem yang baik. Adapun saran yang dimasukan pada UKM Sehati ini untuk mampu melakukan inovasi dan kolaborasi dalam pengembangan usahanya.

\section{UCAPAN TERIMA KASIH}

Terima kasih kepada pihak-pihak yang sudah terlibat dalam pelaksanaan pengabdian kepada masyarakat, sehingga kegiatan ini dapat terlaksana tanpa kekurangan sesuatu apapun, adapun pihak yang terlibat sebagai berikut:

1. P3M Universitas Majalengka

2. Desa Cibentar Kecamatan jatiwangi kabupaten Majalengka 
3. Civitas akademik Universitas Majalengka.

\section{DAFTAR PUSTAKA}

[1] Bismala, L., Handayani, S., Andriany, D., \& Hafsah. (2018). Strategi Peningkatan Daya Saing Usaha Kecil Menengah. Medan : Lembaga Penelitian dan Penulisan Ilmiah Aqli.

[2] Henri. 2019. Jawa Barat Prioritas Menjadi Kawasan Industri Baru. www.berita.id. Diakses 28 Desember 2020.

[3] Yulianto. 2020. Hadapi AKB atau New Normal, Pelaku UMKM Majalengka Diminta Miigrasi ke Digital. www.tribuncirebon.com. Diakses 28 Desember 2020.

[4] ASTRO. "Deep Fryer Gas \& Listrik". 2020. [Online]. Available: https://astromesin.com/mesin-deepfryer/. [Accessed: December 28, 2020].

[5] Ikatan Akuntan Indonesia. (2018). Standar Akuntansi Keuangan Mikro, Kecil dan Menengah. Jakarta: Ikatan Akuntan Indonesia. 